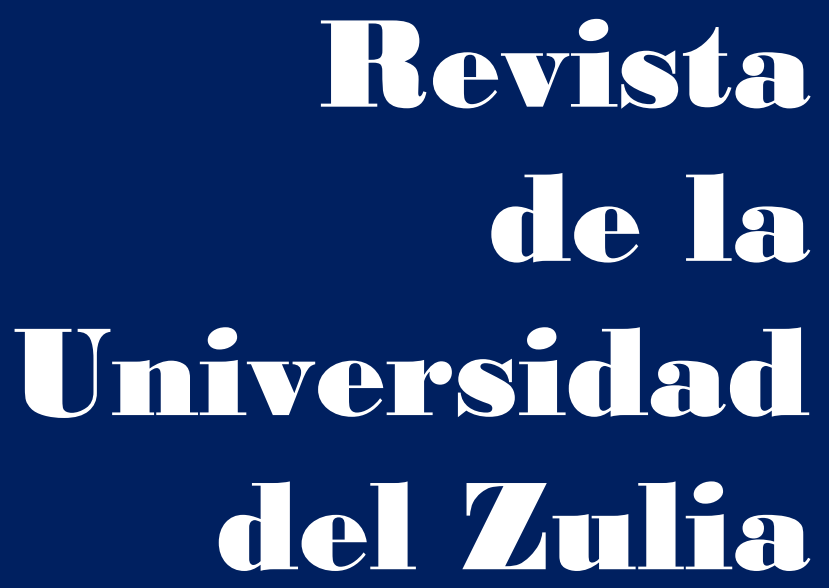

Fundada en 1947

por el Dr. Jesús Enrique Lossada

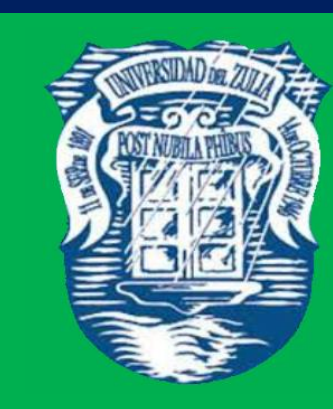

Ciencias del

Agrad,

Ingemiería

y Tecinología

\section{Aกัต 13 No $\mathbf{3 6}$} Enero - Abril 2022

Tercera Épaca

Maracailbo-Venezuela 
REVISTA DE LA UNIVERSIDAD DEL ZULIA. $3^{a}$ época. Año $13 \mathrm{~N}^{\circ}$ 36, 2022

Gamlet Y. Ostaev et al. /// Internal control in the economic security system of agricultural ... 140-157 DOI: $\underline{\text { http://dx.doi.org/10.46925//rdluz.36.10 }}$

\title{
Internal control in the economic security system of agricultural and processing organizations
}

\author{
Gamlet Y. Ostaev* \\ Boris N. Khosiev** \\ Zamir M. Azrakuliev *** \\ Valentina B. Dzobelova **** \\ Anna Kh Kallagova *****
}

\begin{abstract}
The article reveals the need for internal control in the economic security system of agricultural and processing organizations. The objective of the study is to establish the function of internal control in the economic security system of agricultural and processing organizations, as a mechanism for identifying risks and threats. In accordance with this objective, the main task was determined, to substantiate the theoretical and practical aspects of internal control in the economic security system of agricultural and processing organizations. The work examines the substantive and formal methodological aspects, including the study of laws, theories, the structure of scientific knowledge, the analysis of research methods from the point of view of logical structure and the formalized approaches for the construction of the theoretical knowledge, its truth and argumentation. The classification of internal control in the organization's economic security system is offered. A list of mandatory internal control elements has been determined in the organization's economic security system. The methods and procedures are grouped by functional components in the economic security system.
\end{abstract}

KEY WORDS: agricultural organization; dairy industry; Organization and management; Business economics.

* Candidate of Economic Sciences, Associate Professor of Accounting, Finance and Audit, Izhevsk State Agricultural Academy, 426069, Izhevsk, Studencheskaya Street, 11 Spin-code: 3674-4120. ORCID: https://orcid.org/0000-0003-0869-7378.

** Candidate of Economic Sciences, Professor, Head of the Department of Economic Security, Accounting, Finance and Audit, Gorsky State Agrarian University, 362040, RNO-Alania, Vladikavkaz, Kirov Street, 37 Spin-code: 38215340. ORCID: https://orcid.org/0000-0002-5241-872X.

*** Candidate of Economic Sciences, Associate Professor, Head of the Department of Accounting, Finance and Audit, Dagestan State Agricultural University named after M.M. Dzhambulatova, 367032, Republic of Dagestan, Makhachkala, M. Gadzhieva Street, 180, Spin-code: 4435-9422. ORCID: https://orcid.org/0000-0002-8129-2249.

**** Candidate of Economic Sciences, Associate Professor, Department of Finance, Accounting and of taxation. North-Ossetian State University named after K.L. Khetagurov, 362025 Vladikavkaz, Vatutina Street, 44-46, Spincode: 6557-7540. ORCID: https://orcid.org/0000-0001-7673-3559.

***** Candidate of Economic Sciences, Associate Professor of the Department of Economics and Finance, Financial University under the Government of the Russian Federation, Vladikavkaz branch, 362002, Vladikavkaz, Youth Street, 7, Author ID: 1050052. ORCID: https://orcid.org/0000-0001-5492-5429. 
REVISTA DE LA UNIVERSIDAD DEL ZULIA. $3^{a}$ época. Año $13 \mathrm{~N}^{\circ}$ 36, 2022

Gamlet Y. Ostaev et al. /// Internal control in the economic security system of agricultural ... 140-157 DOI: http://dx.doi.org/10.46925//rdluz.36.10

\section{Control interno en el sistema de seguridad económica de las organizaciones agrícolas y de procesamiento}

RESUMEN

El artículo revela la necesidad del control interno en el sistema de seguridad económica de las organizaciones agrícolas y de procesamiento. El objetivo del estudio es fundamentar la función del control interno en el sistema de seguridad económica de las organizaciones agropecuarias y de procesamiento, como mecanismo de identificación de riesgos y amenazas. De acuerdo con este objetivo, se determinó la tarea principal, fundamentar los aspectos teóricos y prácticos del control interno en el sistema de seguridad económica de las organizaciones agrícolas y de procesamiento. El trabajo examina los aspectos metodológicos sustantivos y formales, incluyendo el estudio de las leyes, las teorías, la estructura del conocimiento científico, el análisis de los métodos de investigación desde el punto de vista de la estructura lógica y los enfoques formalizados para la construcción del conocimiento teórico, su verdad y argumentación. Se ofrece la clasificación del control interno en el sistema de seguridad económica de la organización. Se ha determinado una lista de elementos obligatorios de control interno en el sistema de seguridad económica de la organización. Los métodos y procedimientos se agrupan por componentes funcionales en el sistema de seguridad económica.

PALABRAS CLAVE: organización agrícola; industria lechera; organización y gestión; Economía de la empresa.

\section{Introduction}

The aim of the study is to substantiate the function of internal control in the system of economic security of agricultural and processing organizations, as a mechanism for identifying risks and threats.

Many scientists believe that internal control is necessary only in terms of identifying internal risks and identifying deviations reflected in accounting documents. However, many authors focus on internal control as an adaptive mechanism in the context of the economic security of an organization.

The organization's economic security system in modern times should be based on many internal control and analytical, resource and accounting principles and technical and technological approaches (Kontsevaya S. R., 2018).

Control is a universal mechanism and management function of the organization, therefore it should be used with the use of methods of economic analysis of factors of production for making management decisions (Kontsevoi G. R. et al., 2020). 
REVISTA DE LA UNIVERSIDAD DEL ZULIA. $3^{a}$ época. Año $13 \mathrm{~N}^{\circ}$ 36, 2022

Gamlet Y. Ostaev et al. /// Internal control in the economic security system of agricultural ... 140-157 DOI: http://dx.doi.org/10.46925//rdluz.36.10

Currently, the computerization processes of management and accounting are rapidly developing, but together with all their advantages they create a fair number of new problems, challenges and threats in the field of organization's economic security (Endovitsky D.A., et al., 2018). In the process of business functioning, as a result of external influences and changes in the internal state of the organization, situations arise that require an immediate response in the form of internal control (Alborov et al., 2017).

Internal control in the organization's economic security system using an indicative approach, factor analysis, other standard measures help to identify the strengths and weaknesses of the organization considering internal risks and external threats (Ostaev G.Ya., et al., 2020). Internal control in the organization's economic security system should cover all methods and procedures required for the collection of information, both on paper and in electronic and cloud media, its processing and study (Kontsevaya S., 2017). The studied information under internal control in the economic security system determines the essence and importance of the identified negative factors, reveals the problem areas of the organization and sets the course for the study of these areas (Rokotyanskaya V. V. et al., 2018).

Internal control of business processes in the organization's economic security system can be classified depending on the type of the current internal control system; specifics of the tasks being solved; time of commission; sources; coverage volumes; the operation level of the internal control system; applied methods for assessing the internal control system.

The classification of internal control in the organization's economic security system depending on the traits is presented in Table 1.

This classification shows the main classification traits of internal control in the system of economic security of the organization. The proposed classification is compiled considering traditional and special methods for the purpose of ensuring the economic security of the organization.

The reform of internal control in the system of economic security of the organization, in fact, should be aimed at expanding the possibilities of control and analytical actions (Mukhina I.A. et al., 2020).

Reform is the most promising of the possible types of development. Reform essentially means changing the shape of something. The practical application of this 
REVISTA DE LA UNIVERSIDAD DEL ZULIA. $3^{a}$ época. Año $13 \mathrm{~N}^{\circ}$ 36, 2022

Gamlet Y. Ostaev et al. /// Internal control in the economic security system of agricultural ... 140-157 DOI: $\underline{\text { http://dx.doi.org/10.46925//rdluz.36.10 }}$ concept in economics suggests a conscious, purposeful, consistently sparing change in the form of economic relations (Kondratiev D. V. et al., 2020).

Table 1. Classification of internal control in the system of the organization's economic security.

\begin{tabular}{|c|c|c|}
\hline It.No. & Classification trait & Classification element \\
\hline 1 & $\begin{array}{l}\text { Depending on the type of the current } \\
\text { internal control system }\end{array}$ & $\begin{array}{l}\text { 1. Non-automated, } \\
\text { 2. Automated; } \\
\text { 3. Mixed. }\end{array}$ \\
\hline 2 & $\begin{array}{l}\text { Depending on the specifics of the tasks } \\
\text { to be solved }\end{array}$ & $\begin{array}{l}\text { 1. Administrative and managerial; } \\
\text { 2. Accounting and analytical; } \\
\text { 3. Technical and technological; } \\
\text { 4. Tax and legal; } \\
\text { 5. Financial and economic, etc. }\end{array}$ \\
\hline 3 & Depending on the execution time & $\begin{array}{l}\text { 1. Preliminary; } \\
\text { 2. Current (operational); } \\
\text { 3. Subsequent (final). }\end{array}$ \\
\hline 4 & Depending on the sources & $\begin{array}{l}\text { 1.Documentary; } \\
\text { 2. Computer; } \\
\text { 3. Actual; }\end{array}$ \\
\hline 5 & Depending on the scope of coverage & $\begin{array}{l}\text { 1. Partial or complete; } \\
\text { 2. Complex or topical; } \\
\text { 3. Solid or selective. }\end{array}$ \\
\hline 6 & $\begin{array}{l}\text { Depending on the level of the internal } \\
\text { control system action }\end{array}$ & $\begin{array}{l}\text { 1. Corporate; } \\
\text { 2. By structural divisions; } \\
\text { 3. At the level of the technological process. }\end{array}$ \\
\hline 7 & $\begin{array}{l}\text { Depending on the methods used for } \\
\text { assessing the internal control system }\end{array}$ & $\begin{array}{l}\text { 1. Visual and actual control methods; } \\
\text { 2. Methods of documentary control using technical } \\
\text { and communication technologies; } \\
\text { 3. Methods of indicative, factorial, standard and } \\
\text { complex control. }\end{array}$ \\
\hline
\end{tabular}

* Author's development

Internal control in the organization's economic security system should include such methods as inventory, visual observation, reverse calculation, examination or laboratory research, comparison, arithmetic verification, logical control of documentation, testing or questioning of personnel, audit, monitoring, official investigation, comprehensive analysis of activities, monitoring, forecasting and modeling.

To achieve the assigned tasks, internal control specialists in the organization's economic security system must develop strategies and plans for control measures.

The plans of control measures in the organization's economic security system should cover control and analytical procedures starting from sampling determination, collection and analysis of information to assessing business processes for their effectiveness (Frantsisko O. Yu., et al., 2020). The strategic objectives in planning and conducting internal control in the 
REVISTA DE LA UNIVERSIDAD DEL ZULIA. $3^{a}$ época. Año $13 \mathrm{~N}^{\circ}$ 36, 2022

Gamlet Y. Ostaev et al. /// Internal control in the economic security system of agricultural ... 140-157 DOI: http://dx.doi.org/10.46925//rdluz.36.10

economic security system of an organization is to assess the causes of deviations, identified remarks/risks and external threats (Molchan A. S. et al., 2020).

The measures of the internal control system in the organization's economic security system should be aimed at collecting evidence, documenting and forming the final control documents.

Factors affecting economic markets or economic relations are identified (determined) studiesi (Ostaev G.Ya., Kondratyev D.V., et al., 2020).

\section{Methodology}

The implementation and creation of a workable internal control system for the purposes of the economic security of agricultural and processing organizations is influenced by a number of factors: the complexity of the organizational structure of the organization, the accounting and management programs used, the qualifications of employees, types of activities, etc.

The theoretical and methodological basis of the study was the works of domestic and foreign scientists. The work investigates substantive and formal methodological aspects, including the study of laws, theories, the structure of scientific knowledge, analysis of research methods from the point of view of the logical structure and formalized approaches to the construction of theoretical knowledge, its truth and argumentation.

The article uses a holistic systematic approach that allows us to consider the internal control system for the purposes of the economic security of the organization. This approach allows you to study the problems of the internal control system for the purposes of the economic security of the organization, to determine its main functions, to outline further development prospects.

The methodological framework used in internal control must be adapted to meet specific goals and objectives, taking into account the available resources, budget and capabilities of the economic entity.

To achieve the goal of the study, general scientific and special methods were used: economic analysis, modeling, observation, comparison and generalization.

\section{Research results and discussion}

For optimal, rational, safe and efficient operation, any system requires internal control. 
REVISTA DE LA UNIVERSIDAD DEL ZULIA. $3^{a}$ época. Año $13 \mathrm{~N}^{\circ}$ 36, 2022

Gamlet Y. Ostaev et al. /// Internal control in the economic security system of agricultural ... 140-157 DOI: http://dx.doi.org/10.46925//rdluz.36.10

The organization's activity as a unified management system is no exception.

Internal control is a process aimed at studying the internal environment of an organization to determine the effectiveness and efficiency of its activities. (Horuzhy L.I., Alborov R.A., 2019).

Internal control should be understood as a process aimed at checking and evaluating one's own work, carried out in their own interests, in order to gain confidence in the effectiveness and constructiveness of their activities (Belozerova L.A. 2019).

The internal control system of the organization must meet the specifics of the financial and economic activities of the organization, operate on an ongoing basis, while the internal documents of the economic entity, which reflect all business processes, are subject to assessment (Kotlyachkov O. V., Denisova N. L. 2014).

The committee of sponsoring organizations of the treadway commission (COSO) has developed a general internal control model against which companies and organizations, including banks, can evaluate their own governance systems.

The elements of internal control according to the COSO system include: control environment; risk assessment; control measures; collection and analysis of information, as well as its transfer to its intended purpose; monitoring and error correction (Internal Control - Integrated Framework, 2013)

Traditionally, all authors and the COSO system attach great importance to the internal environment, while little is paid (do not pay) to the external environment and the economic security of the organization.

It seems to us that internal control in the economic security system of an organization has all the capabilities and controls to assess not only the internal environment, but also to assess external threats, maintain stability, develop and expand prospects.

Currently, economic entities possess high technologies, operate based on high-tech platforms in the field of IT technologies. On high-tech platforms, of agricultural and processing organizations participate in tenders, offer goods (works, services), such a business model is focused on modern business. Accordingly, the requirements, elements, methods, techniques, procedures of internal control in the organization's economic security system are changing.

For the purpose of competent internal control of accounting activities in the of 
REVISTA DE LA UNIVERSIDAD DEL ZULIA. $3^{a}$ época. Año $13 \mathrm{~N}^{\circ}$ 36, 2022

Gamlet Y. Ostaev et al. /// Internal control in the economic security system of agricultural ... 140-157 DOI: $\underline{\text { http://dx.doi.org/10.46925//rdluz.36.10 }}$

agricultural and processing organizations economic security system, the information should be divided into its components presented in table 2 .

Table 2. Information for internal control of accounting and managerial activities in the organization's economic security system.

\begin{tabular}{|c|l|l|}
\hline It.No. & Accounting department & \multicolumn{1}{|c|}{ Information to be researched } \\
\hline 1 & Financial information & $\begin{array}{l}\text { Information about the registration of completed } \\
\text { business transactions and business processes is } \\
\text { investigated from the point of view of legality and } \\
\text { expediency. }\end{array}$ \\
\hline 2 & Production information & $\begin{array}{l}\text { Information on cost accounting, costing of } \\
\text { products (works, services), budgeting and planning } \\
\text { at the production level is studied from the point of } \\
\text { view of arefmeticity, analyticity, cost, profitability, } \\
\text { timeliness and expediency. }\end{array}$ \\
\hline 3 & Management information & $\begin{array}{l}\text { Information about research aimed at business } \\
\text { development is investigated from the point of view } \\
\text { of the timeliness of making strategic decisions, cost } \\
\text { and profitability. }\end{array}$ \\
\hline
\end{tabular}

${ }^{*}$ Compiled by the authors

With this approach of internal control in the agricultural and processing of agricultural and processing organizations economic security system, all deviations at the places of formation and registration of accounting and managerial information will be identified for the business accounting data.

Internal control of risks and threats in the system of organization's economic security is a set of traditional and special control and analytical measures, techniques and procedures for the purpose of timely management of risks and threats.

The purpose of internal control in the agricultural and processing organizations economic security system for controlling risks and threats should be to provide reasonable confidence in the achievement of the tasks set for the business (Table 3).

Internal control in the agricultural and processing organizations economic security system should include a certain list of mandatory elements, which are presented in Figure 1. 
REVISTA DE LA UNIVERSIDAD DEL ZULIA. 3época. Año 13 N 36, 2022

Gamlet Y. Ostaev et al. /// Internal control in the economic security system of agricultural ... 140-157

DOI: $\underline{\text { http://dx.doi.org/10.46925//rdluz.36.10 }}$

Table 3. Target settings of internal control in the organization's economic security system to control risks and threats.

\begin{tabular}{|c|l|l|}
\hline It.No. & \multicolumn{1}{|c|}{$\begin{array}{c}\text { The target of internal } \\
\text { control }\end{array}$} & \multicolumn{1}{c|}{ Target focus/area } \\
\hline 1. & Strategic objectives & $\begin{array}{l}\text { Ensuring financial stability and improving the } \\
\text { financial condition of the business }\end{array}$ \\
\hline 2. & Commutative targets & $\begin{array}{l}\text { Study of the characteristic features of activities, } \\
\text { resources, assets for the purposes of efficient and } \\
\text { economic use, as well as ensuring the safety }\end{array}$ \\
\hline 3 & $\begin{array}{l}\text { Reporting preparation } \\
\text { restructuring objectives }\end{array}$ & $\begin{array}{l}\text { Control over the completeness of accounting } \\
\text { (financial), statistical, managerial and other } \\
\text { reporting and their reliability }\end{array}$ \\
\hline 4 & $\begin{array}{l}\text { Regulatory compliance } \\
\text { objectives }\end{array}$ & $\begin{array}{l}\text { Compliance with applicable business laws and } \\
\text { regulations }\end{array}$ \\
\hline
\end{tabular}

* Author's development

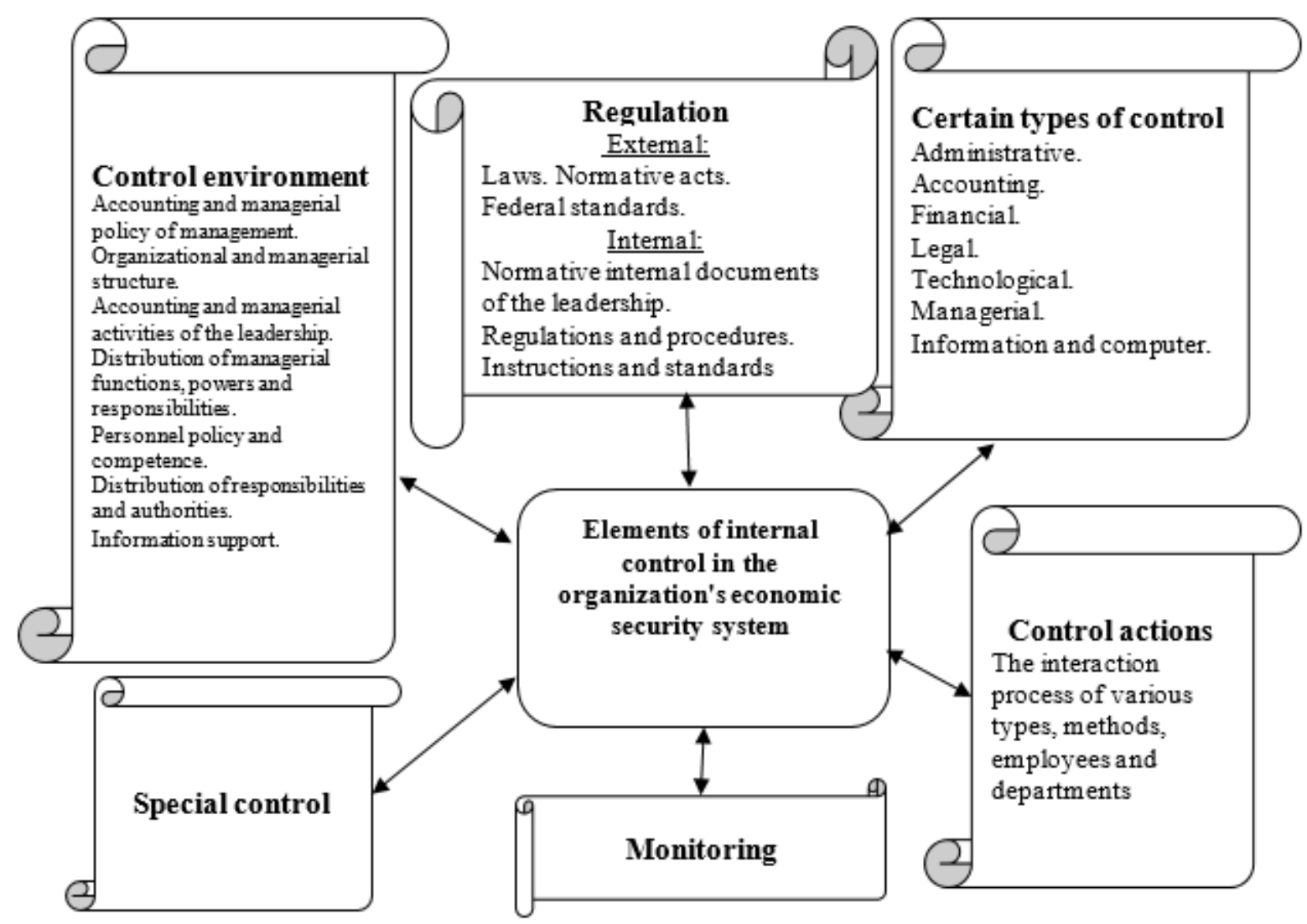

Figure 1. List of mandatory elements of internal control in the economic security system of the agricultural and processing organizations (author's development).

The control environment is the backbone of the agricultural and processing organizations economic security system for the purpose of identifying various accounting deviations, 
REVISTA DE LA UNIVERSIDAD DEL ZULIA. $3^{a}$ época. Año $13 \mathrm{~N}^{\circ}$ 36, 2022

Gamlet Y. Ostaev et al. /// Internal control in the economic security system of agricultural ... 140-157 DOI: http://dx.doi.org/10.46925//rdluz.36.10

internal management and other risks and external threats. The control environment is a foothold for the organization's economic security system covering both the control and accounting system and the organizational and management structure of an economic entity considering the monitoring of the internal and external environment. The internal control apparatus from the point of view of studying the internal environment also reveals the competence of employees considering indicative and other approaches.

Regulatory activity is responsible for the compliance of the internal control system with the regulatory framework of both the agricultural and processing organizations internal (constituent documents, charter, accounting policy and other local regulations) and external environment - compliance with applicable federal legislative acts (federal laws, regulations, provisions, etc.)

Separate types of control, such as administrative, accounting, legal, financial, managerial and informational (computer) make it possible to distribute the workload of the person responsible for organizing internal control (for example, the owner or CEO) in the areas operating within the firm. The purpose of this distribution is to structure the existing internal control regulations in accordance with the specificity of the activities of the organization's departments.

Control actions in the economic security system of an organization in terms of methods, procedures and technologies can be grouped according to certain functional components (Table 4).

Let us consider the practical aspects of internal control in the system of economic security of the organization in terms of the investment business program for the reconstruction of production facilities for milk processing using the example of Megapolis LLC.

Control actions in the organization's economic security system in terms of making an investment decision regarding real investments for Megapolis LLC must be confirmed by functional parameters, which include: production, financial, market, management, etc.

Verification of information using traditional and innovative it-technologies allows for a financial and economic assessment of an investment project. At the same time, all of its functional parameters are checked in value (monetary) terms, which made it possible to obtain an opinion on the organization's investment project. 
REVISTA DE LA UNIVERSIDAD DEL ZULIA. $3^{a}$ época. Año $13 \mathrm{~N}^{\circ}$ 36, 2022

Gamlet Y. Ostaev et al. /// Internal control in the economic security system of agricultural ... 140-157

DOI: $\underline{\text { http://dx.doi.org/10.46925//rdluz.36.10 }}$

Table 4. Grouping of methods and procedures by functional components in the agricultural and processing organizations economic security system.

\begin{tabular}{|c|c|c|c|}
\hline It.No. & $\begin{array}{l}\text { Control action } \\
\text { methods and } \\
\text { procedures }\end{array}$ & $\begin{array}{l}\text { Direction of control methods } \\
\text { and procedures }\end{array}$ & Study and correction \\
\hline 1 & $\begin{array}{l}\text { Information } \\
\text { verification } \\
\text { using traditional } \\
\text { and innovative } \\
\text { IT technologies }\end{array}$ & $\begin{array}{l}\text { Observation tests, visual and } \\
\text { actual control, documentary } \\
\text { verification using technical and } \\
\text { communication technologies }\end{array}$ & $\begin{array}{l}\text { Study of information for } \\
\text { compliance with accounting, } \\
\text { economic and managerial } \\
\text { indicators considering internal } \\
\text { risks and external threats identified } \\
\text { using traditional and innovative } \\
\text { technologies. } \\
\text { Correction of identified } \\
\text { discrepancies obtained from } \\
\text { internal and external sources of } \\
\text { information considering the risks } \\
\text { and threats revealed using } \\
\text { traditional and innovative } \\
\text { technologies. }\end{array}$ \\
\hline 2 & $\begin{array}{l}\text { Data processing } \\
\text { using traditional } \\
\text { and innovative } \\
\text { IT technologies }\end{array}$ & $\begin{array}{l}\text { Grouping and processing of } \\
\text { information considering the } \\
\text { standard and indicative } \\
\text { approach using traditional and } \\
\text { innovative technologies. }\end{array}$ & $\begin{array}{l}\text { Study of grouped and processed } \\
\text { information for compliance } \\
\text { considering internal risks and } \\
\text { external threats identified using } \\
\text { traditional and innovative } \\
\text { technologies. } \\
\text { Correction of the processed } \\
\text { information considering the } \\
\text { accuracy of accounting and } \\
\text { managerial data, the efficiency of } \\
\text { strategic information, internal risks } \\
\text { and external threats identified } \\
\text { using traditional and innovative } \\
\text { technologies. }\end{array}$ \\
\hline 3 & $\begin{array}{l}\text { Data analysis } \\
\text { using traditional } \\
\text { and innovative } \\
\text { IT technologies }\end{array}$ & $\begin{array}{l}\text { Factor analysis of indicators, } \\
\text { analysis of accounting and } \\
\text { managerial documentation, } \\
\text { technical and technological } \\
\text { analysis using traditional and } \\
\text { innovative technologies }\end{array}$ & $\begin{array}{l}\text { Study of information based on the } \\
\text { results of documentary and actual } \\
\text { inventory, factor analysis } \\
\text { considering risks and external } \\
\text { threats identified using traditional } \\
\text { and innovative technologies. } \\
\text { Correction of factor analysis data, } \\
\text { technical and technological analysis } \\
\text { considering internal risks and } \\
\text { external threats identified using } \\
\text { traditional and innovative } \\
\text { technologies. }\end{array}$ \\
\hline
\end{tabular}

* Author's development

In particular, the characteristics of the investment project were studied: the reconstruction of the existing property complex and the organization of the production of 
REVISTA DE LA UNIVERSIDAD DEL ZULIA. $3^{a}$ época. Año $13 \mathrm{~N}^{\circ}$ 36, 2022

Gamlet Y. Ostaev et al. /// Internal control in the economic security system of agricultural ... 140-157 DOI: http://dx.doi.org/10.46925//rdluz.36.10

dairy products. This property complex was acquired by Megapolis LLC under a sale and purchase agreement from Agrosila-Milk LLC on October 30, 2018.

The study revealed that the financing of the project is represented by own and borrowed funds. According to the control information of Megapolis LLC, the company's own funds in the amount of 5.895 million rubles ( $7.0 \%$ of the project cost) were invested in the project in 2019. The total amount of loan funds to finance the project is 80 million rubles, for a period of 10 years with a 1 year deferral of the principal debt payment and an interest rate of $8.5 \%$ per annum. The main direction for the development of credit funds is investments in the increase in working capital for the purchase of raw materials (40.0 million rubles) and the purchase of the necessary equipment (40.0 million rubles).

When processing data using traditional and innovative it technologies, the ratio of own and borrowed funds in project financing was studied. The study showed a high degree of dependence of the project on borrowed funds. This project is financially dependent on borrowed resources and has signs of financial instability.

Table 5 - Study of the distribution of investment costs by structure

\begin{tabular}{|c|l|c|c|}
\hline It.No. & \multicolumn{1}{|c|}{ Cost type } & \multicolumn{1}{|c|}{$\begin{array}{c}\text { Price, } \\
\text { million rubles }\end{array}$} & $\begin{array}{c}\text { Share in total } \\
\text { costs, } \%\end{array}$ \\
\hline \multicolumn{3}{|c|}{ Capital investments } \\
\hline 1 & Equipment & 40,0 & 46,5 \\
\hline 2 & $\begin{array}{l}\text { Investments in the increase in } \\
\text { working capital }\end{array}$ & 40,0 & 46,5 \\
\hline 3 & $\begin{array}{l}\text { Funds previously invested in the } \\
\text { project }\end{array}$ & 5,895 & 7,0 \\
\hline & TOTAL costs & 85,895 & $100,0 \%$ \\
\hline
\end{tabular}

The study showed that the use of own and borrowed funds is necessary for the functioning and development of Megapolis LLC, which specializes in the production of dairy products. Calculations are presented with an indication of a gradual increase in the rate of production of products and their sales, according to the design annual capacity (table 6).

According to the presented Schedule for the development of the design production capacity and reaching the design capacity in 100\% volume, it is planned to be carried out in 2021, i.e. for the 3rd year from the start of the project. Sales volumes, upon reaching full production capacity, will amount to 14,364 tons of products. 
REVISTA DE LA UNIVERSIDAD DEL ZULIA. $3^{a}$ época. Año $13 \mathrm{~N}^{\circ}$ 36, 2022

Gamlet Y. Ostaev et al. /// Internal control in the economic security system of agricultural ... 140-157

DOI: $\underline{\text { http://dx.doi.org/10.46925//rdluz.36.10 }}$

Below are the calculations characterizing the cash flows from the sale of products, according to the sales plan (schedule) (table 7).

Table 6 - Study of the plan (schedule) of sales, tons

\begin{tabular}{|c|c|c|c|c|c|c|c|c|c|c|c|c|c|c|c|}
\hline \multirow{2}{*}{ Sales } & \multicolumn{7}{|c|}{ Schedule for the development of design capacity, taking into account the } \\
& 2019 & 2020 & 2021 & 2022 & 2023 & 2024 & 2025 & 2026 & 2027 & 2028 & $\begin{array}{l}2029 \\
\text { (3mec.) }\end{array}$ & Total \\
\hline $\begin{array}{c}\text { Sales volume } \\
\text { for the period } \\
\text { (tons) }\end{array}$ & 8370 & 11160 & 11160 & 11160 & 11160 & 11160 & 11160 & 11160 & 11160 & 11160 & 2790 & 111600 \\
\hline $\begin{array}{c}\text { Sales volume } \\
\text { for the period } \\
\text { (tons) }\end{array}$ & 72 & 1403 & 2004 & 2004 & 2004 & 2004 & 2004 & 2004 & 2004 & 2004 & 501 & 18008 \\
\hline $\begin{array}{c}\text { Sales volume } \\
\text { for the period } \\
\text { (tons) }\end{array}$ & 48 & 727 & 1200 & 1200 & 1200 & 1200 & 1200 & 1200 & 1200 & 1200 & 300 & 10675 \\
\hline
\end{tabular}

Table 7 - Study of indicators of the cash flow of the investment project, mln. rub.

\begin{tabular}{|c|c|c|c|}
\hline It.No. & Years & $\begin{array}{c}\text { Cash flow * by years of } \\
\text { project implementation }\end{array}$ & Cash flow ${ }^{*}$ cumulative \\
\hline 1 & 2019 & 2,311 & $-77,688$ \\
\hline 2 & 2020 & 43,986 & $-33,701$ \\
\hline 3 & 2021 & 89,772 & 56,071 \\
\hline 4 & 2022 & 85,453 & 141,524 \\
\hline 5 & 2023 & 81,126 & 222,650 \\
\hline 6 & 2024 & 77,061 & 299,711 \\
\hline 7 & 2025 & 73,278 & 372,990 \\
\hline 8 & 2026 & 69,713 & 442,703 \\
\hline 9 & 2027 & 66,123 & 508,827 \\
\hline 10 & 2028 & 62865 & 571,693 \\
\hline 11 & 2029 & 15336 & 587,029 \\
\hline
\end{tabular}

* Cash flow from the point of view of the theory of value

Data processing using traditional and innovative it-technologies showed that the accumulated cash flows for 2019 - 2020. have negative values, which is associated with the gradual development of the maximum possible volume of production (for the 3rd year of the 
REVISTA DE LA UNIVERSIDAD DEL ZULIA. $3^{a}$ época. Año $13 \mathrm{~N}^{\circ}$ 36, 2022

Gamlet Y. Ostaev et al. /// Internal control in the economic security system of agricultural ... 140-157 DOI: http://dx.doi.org/10.46925//rdluz.36.10

organization's work) with the full use of all available resources, as well as with the cost of repaying the loan. The total accumulated flow of the investment project by April 2029 will amount to 587 million rubles. which is 7.3 times higher than the amount of investments, that is, this amount (587 million rubles) of the profit received by the organization at the end of the investment project. We believe that the accumulated volume of cash flow is more expedient to reinvest (invest) in the project (for example, to increase production capacity) in order to obtain additional profit from its implementation.

Data analysis using traditional and innovative it-technologies was aimed at assessing the effectiveness and feasibility of investments (development of a milk processing business) for these purposes, calculations were made to implement the financial model of the project. The main financial indicators are shown in table 8.

Table 8 - Key financial indicators of the project

\begin{tabular}{|c|l|c|c|}
\hline It.No. & \multicolumn{1}{|c|}{ Indicators } & Unit rev. & Meaning \\
\hline 1 & Net Present Value (NPV) & million rubles & 587 \\
\hline 2 & Internal Rate of Return (IRR) & $\%$ & 71 \\
\hline 3 & Payback Period (DPP) & years & 2,5 \\
\hline 4 & Return on Investment Index (PI) & - & 7,3 \\
\hline
\end{tabular}

The study showed that project performance indicators are in line with generally accepted standards for project analysis:

- The net present value (NPV) of the project is above 0 and amounts to 587 million rubles (for 10 years). This is the amount of profit (587 million rubles) that the investor will receive from the implementation of this project, taking into account the time value and risks of all monetary investments in the investment project. The indicator has a positive value, therefore, the project is attractive for investment.

- The internal rate of return (IRR) of the project is $71 \%$, which exceeds the value of the discount rate declared at the level of $6.7 \%$ (WACC is the average cost of all sources of financing), therefore, the investment project has an internal rate of return that is higher than the cost of its own and borrowed capital.

- The payback period of the project, taking into account the factor of the change in the value of money over time, is 2.5 years, this is the minimum period for which the accumulated income will exceed the amount of the invested funds; 
REVISTA DE LA UNIVERSIDAD DEL ZULIA. $3^{a}$ época. Año $13 \mathrm{~N}^{\circ}$ 36, 2022

Gamlet Y. Ostaev et al. /// Internal control in the economic security system of agricultural ... 140-157 DOI: http://dx.doi.org/10.46925//rdluz.36.10

- The index of return on investment (a relative indicator of investment efficiency) is 7.3. It shows the level of income received per one ruble of investment, taking into account the time value of money, that is, by 2029, the organization will receive 7.3 rubles of income for each ruble of investment invested.

These indicators indicate that the project is paying off and is able to bring additional profit to the initiators of the project.

The return on sales, as one of the main financial indicators for assessing the effectiveness of the organization, at the time of reaching the design capacity in 2021, will be $9.8 \%$, that is, in every ruble earned, the organization will have about 10 kopecks of net profit. This result will be achieved with the forecasted revenue volume of RUB 1,192.1 million. and profit from production and sales of products in the amount of 116.9 million rubles.

The average profitability of sales from the moment of reaching profit from production and sales of products (from 2021) to the end of the project is $8.6 \%$. In the methods of express analysis, it is established that a net profit margin of more than $10 \%$ means successful activity, the level of profitability from $5 \%$ to $10 \%$ is assessed as a relatively good result, and profitability below 5\% or losses are interpreted as failure. According to the results of the project, this indicator characterizes a good work result, but for a more meaningful assessment, let us compare the profitability of the organization (8.6\%) with the results of its competitors.

Profitability indicators are higher than the industry average values of competing enterprises, the level of which is determined at 8.2\% (food industry) (according to data established by the Federal Tax Service of the Russian Federation, Appendix No. 4 to Order of the Federal Tax Service of Russia No. MM-3-06 / 333 @ dated May 30, 2007). Control actions in terms of methods, procedures and technologies confirmed the viability of the project and, consequently, the economic security of the organization.

The list of measures related to the monitoring of control means in the agricultural and processing organizations economic security system includes:

1. Supervision of the internal control apparatus over the implementation of control and analytical, monitoring and evaluation activities within the economic entity;

2. Assessment of the internal control apparatus of accounting and analytical information provided by the economic and accounting department of the organization; 
REVISTA DE LA UNIVERSIDAD DEL ZULIA. $3^{a}$ época. Año $13 \mathrm{~N}^{\circ}$ 36, 2022

Gamlet Y. Ostaev et al. /// Internal control in the economic security system of agricultural ... 140-157 DOI: http://dx.doi.org/10.46925//rdluz.36.10

3. Analysis of employees' competence of an economic entity and the timeliness of their work preparation in accordance with their job descriptions;

4. Supervision over the compliance of accounting, storage of the organization's assets, implementation of contractual relations, internal ethical standards;

5. Assessment of technical means of control, corrective measures considering risks and threats.

Monitoring should cover all internal resources, accounting and management documents, information obtained from internal and external sources.

Special control, being a separate structural unit of control operating in an agricultural and processing organization, is a universal element and an applied tool of the organization's economic security system, which identifies internal risks and external threats.

The main elements of the economic security system in the implementation of the agricultural and processing organizations internal control are shown in Figure 2.

Digital technologies including software products in the work of internal control in the agricultural and processing organizations economic security system allow minimizing risk factors.

Summarizing all the studied information of internal control the facts that revealed considering the measures taken should be used and are fully disc losed.

In the organization's economic security system, internal control is the core of an orderly, systemic, organized and applied element of achieving the efficiency of an economic entity's functioning.

\section{Conclusion}

Thus, internal control in the organization's economic security system in a "complex" is a complicated, multifaceted economic phenomenon characterized by many factors and conditions, by analyzing of which it is possible to identify business development trends considering internal risks and external threats.

Despite the complexity and specificity of internal control in the economic security system, agricultural and processing organizations must constantly collect and process information in order to reduce various threats and risks. The problems of internal control in the economic security system are relevant and follow constant and active improvement. 


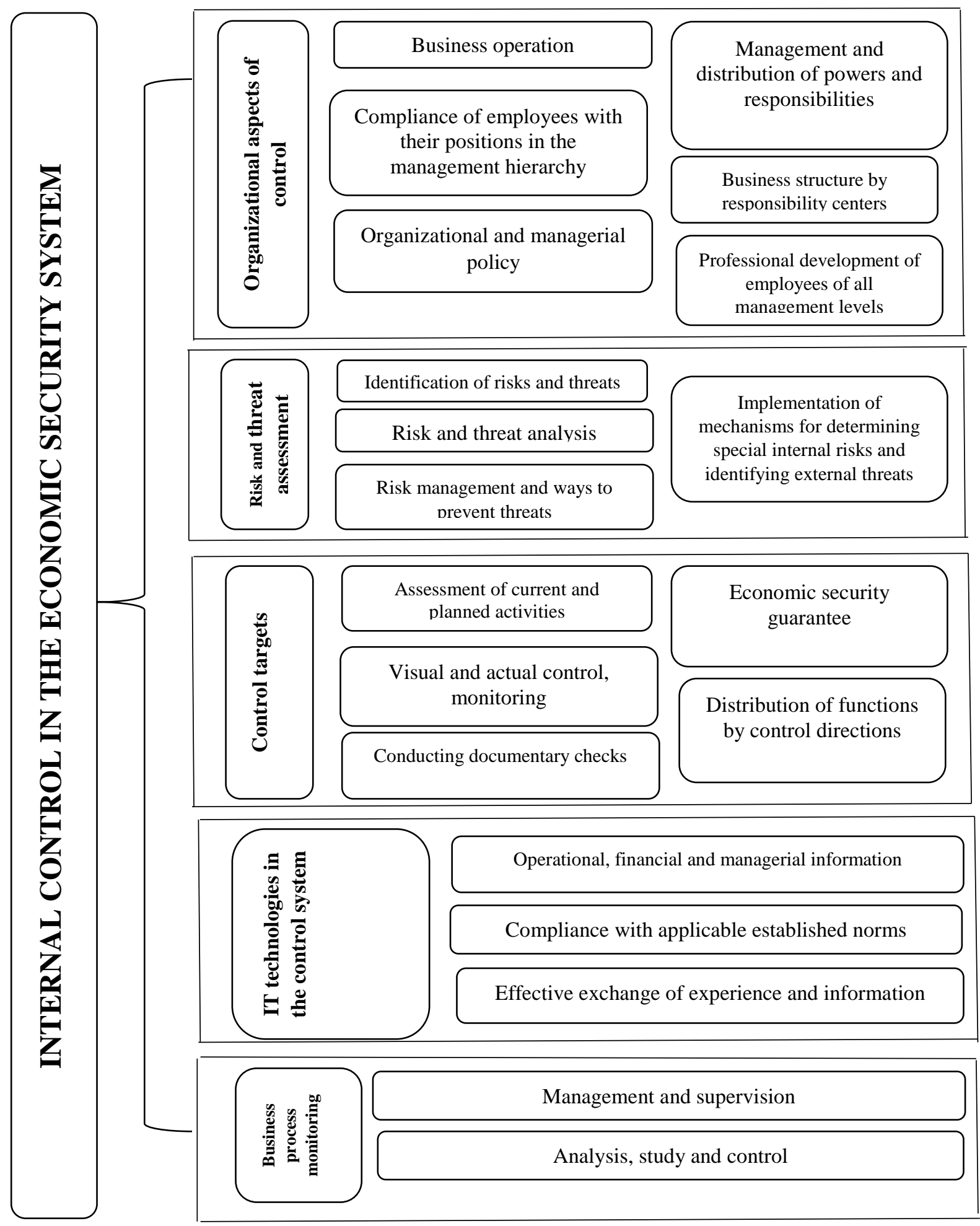

Figure 2. The structure of internal control in the economic security system of the agricultural and processing organizations (author's development). 
REVISTA DE LA UNIVERSIDAD DEL ZULIA. $3^{a}$ época. Año $13 \mathrm{~N}^{\circ}$ 36, 2022

Gamlet Y. Ostaev et al. /// Internal control in the economic security system of agricultural ... 140-157 DOI: $\underline{\text { http://dx.doi.org/10.46925//rdluz.36.10 }}$

\section{References}

Alborov R. A. et al. (2017). The development of management and strategic management accounting in agriculture. Journal of Engineering and Applied Sciences 12(19) 4979-4984. (DOI: 10.3923/jeasci.2017.4979.4984)

Belozerova L.A. (2019). The role and significance of internal control in the activities of the organization .Young scientist. 24 (262) 316-320.

Endovitsky D.A., Durakova I.B. (2018). Statistical analysis as the basis for the practice of modernizing personnel management: international experience. International Journal of Engineering and Technology (UAE). 7(4): 145-151.

Frantsisko O. Yu. et al. (2020). Formation of an integrated system for monitoring the food security of the region. Amazonia Investiga 9(25) 59-70/

Horuzhy L.I., Alborov R.A. (2019). Methodology for monitoring the reliability of indicators in the accounting (financial) statements of an organization. IPB Bulletin (Bulletin of Professional Accountants) 4 6-14.

Kondratiev D. V. et al. (2020). Organizational and management mechanism for reforming agricultural organizations based on cooperation and integration of economic systems. Amazonia Investiga 9(25) 376-388.

Kontsevaya S. (2017). Managerial accounting and agricultural efficiency control in Russia. Agrarian Perspectives XXVI: Competitiveness of European Agriculture and Food Sectors. Proceedings of the 26th International Scientific Conference 145-150.

Kontsevaya S. R. (2018). Comparison analysis and control procedures of labor workforce efficiency of milk processors in visegrad group and Russia. Acta Universitatis Agriculturae et Silviculturae Mendelianae Brunensis 66 (1) 263-272/

Kontsevoi G. R. et al., (2020). Management accounting of agricultural production: improving planning and standardization of costs in the management information system. Amazonia Investiga 9(27) 284-293. (DOI: https://doi.org/10.34069/AI/2020.27.03)

Kotlyachkov O. V., Denisova N. L. (2014). The place of internal control in the cost management system of an economic entity. Educational environment today and tomorrow. Collection of scientific papers of the IX International Scientific and Practical Conference. edited by G.G. Bubnova, E.V. Pluzhnik, V.I. Soldatkina. 232-233.

Molchan A. S. et al. (2020). Optimization of interaction of agrarian entities as an imperative of ensuring food security of the state. Amazonia Investiga. 9(26) 242-253. (https://doi.org/10.34069/AI/2020.26.02)

Mukhina I.A. et al. (2020). Migration processes in rural areas as an indicator of economic security. Amazonia Investiga. 9(28) 330-337. (https://doi.org/10.34069/AI/2020.28.04) 
REVISTA DE LA UNIVERSIDAD DEL ZULIA. $3^{a}$ época. Año $13 \mathrm{~N}^{\circ}$ 36, 2022

Gamlet Y. Ostaev et al. /// Internal control in the economic security system of agricultural ... 140-157 DOI: $\underline{\text { http://dx.doi.org/10.46925//rdluz.36.10 }}$

Ostaev G.Ya., et al. (2020). Accounting agricultural business from scratch: management accounting, decision making, analysis and monitoring of business processes. Amazonia Investiga. 9(27) 319 -332. (DOI: https://doi.org/10.34069/AI/2020.27.03)

Ostaev G.Ya., Kondratyev D.V., et al. (2020). Foresight research in management accounting: scenario forecasting and a comprehensive system of expert assessment methods in agricultural holdings. Amazonia Investiga. 9 (29) 188-203. (https://doi.org/10.34069/AI/2020.29.05)

Rokotyanskaya V. V. et al. (2018). Control and analytical management aspects of debtor and credit deposit of enterprises. Journal of Applied Economic Sciences 132 (56) 446-453. 